\title{
The Determinants of Bilateral Trade within the CEMAC Bloc: Evidence Using the Augmented Gravity Model and the PPML Estimation Technique
}

\author{
Ekwelle Metougue Eric $^{1 *} \quad$ Molem Sama $^{2} \quad$ Dobdinga Cletus $^{3}$ \\ 1. Doctoral Candidate, University of Buea, Cameroon \\ 2. Professor in Economics, University of Buea, Cameroon \\ 3. Associate Professor in Economics, University of Buea, Cameroon
}

\begin{abstract}
Due to the relatively low levels of bilateral trade flows observed within the CEMAC bloc as well as the poor rates of economic growth observed in CEMAC member States, the study aimed to examine the determinants of bilateral trade flows within the CEMAC bloc using the Augmented Gravity model as the main theoretical framework. While secondary data for bilateral trade was obtained from IMF's Direction of Trade Statistics, secondary data for Gross Domestic Product (GDP), population size and investment in fixed capital were obtained from the World Bank's World Development Indicators and data for distance and CEMAC dummy were obtained from the Institute for Research on the International Economy (CEPII). Using the Pseudo-Poisson Maximum Likelihood (PPML) technique, the results of the study conclude that while GDP of exporting country, GDP of importing country, the existence of a border between exporting country and importing country, population of exporting country, population of importing country, physical capital of exporting country and physical capital of importing country all have positive and significant impact on bilateral trade flows within the CEMAC bloc, distance between exporting country and importing country and the creation of CEMAC as a trade bloc all have negative and significant impact on bilateral trade flows within the CEMAC bloc. Finally, the study recommends that policy makers of the CEMAC trade bloc design and implement policies and measures that are geared towards boosting the GDP of member States, investing in national and regional infrastructural projects, eradicating barriers at their respective borders, investing in the acquisition and transfer of technical and technological skills, harmonizing regional financial, economic, legal and trade policies and improving the business (investment) climate.
\end{abstract}

Keywords: Bilateral Trade, Economic Growth, Augmented Gravity Model, CEMAC, PPML.

DOI: $10.7176 / \mathrm{JESD} / 11-16-09$

Publication date: August $31^{\text {st }} 2020$

\section{Introduction}

Over the years, there has been a general consensus among the various schools of thought in Economics on the stimulating effect of international trade on economic growth irrespective of whether policymakers use import substitution or export oriented trade strategies. Authors such as Krugman (1979) and Bernard et al. (2003) amongst others argue that trade promotes the efficient allocation of resources, allows countries to experience the benefits of economies of scale, facilitates the diffusion of knowledge, fosters technological progress and encourages competition both in domestic and international markets that leads to an optimization of the production processed and the development of new products.

The belief that international trade stimulates economic growth is echoed by a good number of schools of economic thought. The Marxist school championed by Karl Marx believes that trade encourages continuous production which further encourages employment with the long-term effect been a boost in economic growth. From the Classical point of view championed by Adam Smith and David Ricardo, international trade improves productivity and ensures the optimal distribution of resources which eventually leads to economic growth. The new growth school championed by Romer and Lucas argues that international trade could promote economic growth through technological spill over. They further stress that international trade provides a broader market scope, leads to more fluidity in communication and information exchanges and encourages competition which serves as a stimulant for countries to compete for technology. The boom in technological spill overs will therefore form a basis for economic growth. Lastly, the new trade theory championed by Paul Krugman argues that the optimal allocation of resources and economies of scale are the two main ways through which international trade promotes economic growth.

As a result of the a priori advantages that international trade has to offer, it is very crucial that policy makers understand the factors that determine bilateral trade between nations. By understanding the factors that determine bilateral trade, this will act as a sine qua non in designing and implementing appropriate and practical policies that are geared towards boosting bilateral trade between nations.

For the case of the CEMAC Bloc (made up of six countries including Cameroon, Gabon, Chad, Equatorial Guinea, Republic of Congo and the Central African Republic), despite the creation of institutional structures such 
as the Monetary Union of Central African States (UMAC) which is in charge of financial integration and the Economic Union of Central African States (UEAC) which is in charge of economic integration and the putting in place of the CEMAC Regional Economic Program (PER), bilateral trade flows and economic growth within the Bloc has not been encouraging.

According to UNCTAD Statistics (2019), when compared to other Regional Trade Arrangements in Africa, the value of merchandise trade for the CEMAC region is relatively smaller. In 2018 for instance, while CEMAC realized only 29,569 million US Dollars as value in merchandise trade, other trade blocs realized the following; Arab Maghreb Union (112,010 million US Dollars), the Community of Sahel Saharan States (209,283 million US Dollars), the Common Market for Eastern and Southern Africa (117,063 million US Dollars), the Economic Community of West African States (108,490 million US Dollars), the South African Customs

Union (108,955 million US Dollars) and the Southern African Development Community (188,201 million US Dollars).

This poor performance in CEMAC bilateral trade is corroborated by the poor performance in economic growth rates of CEMAC member Countries. Statistics from the World Bank's World Development Indicators (2019) indicate that the GDP growth rate of individual CEMAC countries and the region has a whole has been very mediocre. The statistics indicate that, since after the creation of CEMAC, apart from Equatorial Guinea that has witnessed a double digit GDP growth rate of over $14.217 \%$, others have witnessed just very slight improvements as is the case with Cameroon (0.853\%), Central African Republic (0.179\%) and Chad (3.909\%). Worst still, other countries have witnessed a drop in their GDP growth rate as is the case with Gabon (-2.961\%) and Congo Republic (-1.343). If we consider the CEMAC region as a whole, we observe that since after the creation of the CEMAC region, GDP growth rate has improved only by a single digit of 4.089 .

Given the resounding role of international role on the economic growth of nations, it is crucial to understand the factors that determine trade flows between nations engaged in trade. In order to understand the factors that determine bilateral trade within the CEMAC bloc, this study makes use of the Gravity model which is largely attributed to Jan Tinbergen (1962).

In simplistic terms, the Gravity model states that trade between two countries is positively related to the economic masses of the two trading economies and is negatively related to the trade costs between the two economies. The implication here is that larger economies tend to trade more than smaller economies and larger trade costs tend to reduce trade between the two economies. The value of GDP is used as a proxy for the economic masses of the two economies and variables such as distance, border, investment in fixed capital and the existence of a regional trade agreement amongst other variables which are used as proxies to trade costs.

In this light, the study seeks to answer the following main research question; what are the determinants of bilateral flows in the CEMAC Bloc? The specific research question is; to what extent do GDP of trading partners, population of trading partners, distance between trading partners, physical capital of trading partners, the existence of a common border between trading partners and the creation of CEMAC as an Regional Trade Agreement determine bilateral trade flows within the CEMAC Bloc?

In this same light, the study has as main objective to examine the determinants of bilateral trade within the CEMAC bloc. The specific objective is to examine how the GDP of trading partners, the population of trading partners, the distance between trading partners, physical capital of trading partners, the existence of a common border between trading partners and the creation of CEMAC as an RTA determine bilateral trade within the CEMAC Bloc.

Stated in its null form, the study has the following hypothesis; GDP of trading partners, distance between trading partners, population of trading partners, physical capital of trading partners, the existence of a common border between trading partners and the creation of CEMAC as an RTA do not determine bilateral trade within the CEMAC Bloc.

\section{Literature Review}

The main theoretical inspiration for this study is the Gravity model. The Gravity model is used as the main theoretical framework in explaining the determinants of bilateral flows within the CEMAC Bloc. The gravity model was first applied by Tinbergen (1962) to explain the trend of bilateral trade flows among nations. According to De Groot et al. (2004), the gravity model draws its inspiration from the Newtonian equation of the force of gravity in physics. The model assumes that, just as the nine planets attract together relative to their sizes and proximity, countries trade according to their respective GDPs and proximity.

In other words, the gravity model postulates that the volume of bilateral trade between countries is a function of their economic size measured by their gross domestic product (GDP) and the geographical distance between the trading partners. Also, according to Anaman and Quayson (2003), the gravity model states that bilateral trade flows between countries are determined by factors which either reduce or increase these flows. According to Krugman et al. (2012), the basic form of the gravity model is written as: 


$$
T_{i j}=A \frac{Y_{i}^{a} \times Y_{j}^{b}}{D_{i j}^{c}}
$$

Where A represents the gravitational constant of proportionality, $T_{i j}$ is the value of trade (i.e. sum of imports and exports) between country $\mathrm{i}$ and country $\mathrm{j}, Y_{i}$ and $Y_{j}$ represent their GDPs while $D_{i j}$ is the distance between the two countries' economic centres and $\mathrm{a}, \mathrm{b}$ and $\mathrm{c}$ are estimable parameters.

According to this equation, the trade between any two economies is directly proportional to their GDP. Hence, the larger the economy, the higher the volume of trade. On the other hand, geographical distance has an inverse relationship with the value of trade, thus impeding trade flows. According to Baxter and Kouparistas (2006), the farther the distance between countries, the higher the transportation costs which will consequently lead to a reduction in the gains from trade thereby leading to reduced trade flows between trading partners.

Apart from GDP of trading partners and the distance between trading partners, authors such as Garcia et al. (2013), Kabir et al. (2017) and Baier et al. (2014) amongst many other authors have extended the original gravity model by Tinbergen (1962) by adding other variables that affect trade. Some of these variables include population of exporting and importing country, investment in fixed capital (transport infrastructure) in both home and foreign country, a common border dummy, a common language dummy, a common colonial heritage dummy, a landlocked dummy and a Regional Trade Agreement (RTA) dummy amongst many other variables.

A number of studies such as those of Guan and Sheong (2020), Fatima et al. (2019), Oparanya et al. (2019), Osabuohien et al. (2019), Irshad et al. (2018), Umo-Udo and Orifa (2018), Akpoilih and Farayibi (2015), Husain and Yasmin (2015), Panda et al. (2016), Iqbal and Islam (2014), Zeray and Gachen (2014), Bonuedi (2013), Garcia et al. (2013), Khan et al. (2013), Ntembe (2012), Turkson (2012), Anaman and Atta-Quayson (2009), Gani (2008), Tri Do (2006), Linders et al. (2005) and De Groot et al. (2014) amongst others.

Guan and Sheong (2020) analysed the different factors affecting Sino-African (China-African) trade. With the use an augmented gravity model and using a System Generalized Method of Moments (GMM) estimation technique, the findings reveal that China's GDP and the GDP of African countries have a negative but significant effect on African exports to China and have a positive effect on African imports from China. Also, the findings reveal that real exchange rate affects African exports to China positively and affects African imports from China negatively. Again, the findings reveal that population affects African exports to China significantly and positively and affects African imports from China positively. Moreover, recession was found to have negative effects on both African imports from China and exports to China but was only significant for imports. Finally, trade agreement between China and Africa was found to affect African imports from China and exports to China positively. The study recommends that the structure of African products exported to China should be improved and that trade agreements between China and Africa should be reinforced.

Fatima et al. (2019) estimated the impact of different factors affecting Pakistan's bilateral trade with its major trading partners. Panel data set for different variables including GDP, per capita income, population and membership with different International Organizations were taken from different sources for the time period 1995 to 2016. Making use of the Fixed and Random Effects estimation techniques within the augmented gravity trade model, empirical findings reveal that the GDP of trading partners, trade to GDP ratio and population of Pakistan have a significant and positive impact on the bilateral trade of Pakistan with its major trading partners. Also, while GDP has a positive but insignificant impact on Pakistan's bilateral trade, distance between trading countries and population of trading partners have negative and insignificant impact on Pakistan's bilateral trade. Finally, Trade Organizations also have negative and insignificant impact on Pakistan's bilateral trade. The study recommends that Pakistan should implement measures that increase trade between Pakistan and its trading partners.

Oparanya et al. (2019) examined the determinants of bilateral trade flows within the East African Community (EAC) over the time period 1970 to 2010 . Using the Random Effects model, the findings of the study suggest that country size, contiguity, diaspora remittances and corruption index have a positive impact on the region's bilateral trade. On the other hand, foreign direct investment flows, net population effects and mobile subscription ratio have a negative impact on intra-trade flows among member States. The study recommends that member States of the East African Community should consistently seek to address the obstacles that impede trade among themselves in order to enhance their gains from international trade.

Osabuohien et al. (2019) examined the performance of bilateral trade in West Africa using the Gravity model over a time period from 2006 to 2013. The study provides empirical insights on the functioning of Regional Trade Agreements within the Economic Community of West African States (ECOWAS) by identifying bilateral trade barriers that affect the extent of trade flows among member countries. Also, it highlights some trade barrier indicators that are rarely covered in extant studies such as the multilateral resistance term, the extent of trade complementarity and the presence of economic integration agreements. With the use of the PPML Estimation Technique and the augmented gravity model, the study finds that trade complementarity had a positive and significant effect on bilateral trade within the sub-region. The study recommends that countries should be encouraged to belong to RTAs as a bid to increase their trade potentials. 
Irshad et al. (2018) analysed Pakistan's bilateral trade and trade potential with China over a time period from 1992 to 2005 within the framework of the Pakistan-China Free Trade Area (PCFTA). In an attempt to obtain unbiased results, the study applies the Estimated Generalized Least Square (EGLS) technique, the Random Effect model (REM), the two stage EGLS, Tobit as well as the Pseudo Poisson Maximum Likelihood (PPML) estimation technique within a gravity model framework. The results indicate that Pakistan's bilateral trade with China is positively affected by the GDP of trading partners, religion, WTO dummy, trade openness in both countries and the common border dummy. On the other hand, bilateral trade flows are negatively affected by geographical distance and inflation. Finally, the overall PTA effect was found to be negative but highly significant. The study recommends that Pakistan should adopt new measures to boost and diversify its exports to China and bring about a reasonable equality in mutual trading relations.

Umo-Udo and Orifa (2018) assessed Nigeria's bilateral trade relations with China for the time period from 1999 to 2016. To achieve this objective, historical descriptive method was adopted and data was collected during secondary sources. Content analysis was used to evaluate the three research questions posited in the study. The major findings of the study revealed amongst others that the relationship Nigeria had with its Chinese counterpart had developed a wide range of trade imbalance between the two countries. The findings also revealed that between 2013 and 2016, Nigeria's trade deficit with China was 1.9 million US Dollars. In fact, Chinese investment and industrialization in Nigeria was far beyond the expectations of Nigerians compared to what they are gaining from Nigeria. Based on the above findings, they recommended amongst other things that an effective approach to address the trade imbalance was to initiate a cooperative mechanism that would enable Nigeria increase its export of manufactured goods to China. Also, they recommended that Nigeria should adapt to its current socio-economic transformation and emulate the Chinese model as it rallies to industrialize its economy. Finally, they recommended that Nigeria should adopt severe measures in the fight against corruption.

Panda et al. (2016) analysed the bilateral trade flows of two of the emerging economies namely China and India with an objective to draw a comparison between the determinants of bilateral trade flows of the two nations using data for a period of 9 years (2004- 2013). Using the gravity model framework, the study employs random effects panel regression model to establish the relationship between bilateral trade flows and different variables including distance, gross domestic product, per capital income, contiguity, common language and common colonizer. It compares the determinants of bilateral trade for India with China. The findings of the empirical analysis are in accordance with past literature indicating that India and China trade flows are mostly with geographically closer countries. Additionally, India's trade flows are with countries having higher GDP. China's trade is influenced by higher per capita income of the trading partner and common language. When crisis was introduced in the analysis, post crisis and common colony became important influencers of bilateral trade for India. This study helps in identifying the key determinants of India and China's bilateral trade flows. It also provides a pre and post crisis analysis of the trade partnerships which might have future implications for trade policy and trade relations for the two countries.

Akpoilih and Farayibi (2015) analysed the determinants of bilateral trade relation in manufacturing products between Nigeria and China for the period 1995 to 2012. Using the Gravity Trade model, they found that economic size measured by GDP had a significant positive relationship with total exports while distance posed a significant negative relationship. This paper therefore recommended the diversification of the economic base of Nigeria crucial for a more beneficial China-Nigeria bilateral trade in manufactures.

Husain and Yasmin (2015) investigated the determinants of bilateral trade flows of Bangladesh with her fifty two major trading partners with the use of trade gravity model approach. The gravity model was estimated using pooled Ordinary Least Squares (OLS), fixed effects, random effects estimation technique with the help of panel data for the period 1975-2005. The estimation results show that trade volume of Bangladesh responds more than proportionally to per capita GDP and distance for Organization for Economic Cooperation and Development (OECD) and non-OECD trading partner countries separately. Bangladesh's direction of trade pattern is also strongly governed by geographical characteristics implying Bangladesh has a tendency to trade with larger countries. Membership in OECD and Generalized Scheme of Preferences (GSP) dummy has significant impact on trade. The results of gravity models have also been applied to calculate the trade potentials indicating that Bangladesh has unexploited trade potentials with countries like the United Kingdom, Singapore, Netherlands, Germany, the United Arab Emirates, Canada, India, China, Italy, Australia, Germany, Switzerland and Pakistan. The study therefore recommends that Bangladesh's unexploited trade potentials with its trading partners should be identified and utilized for this will go a long way in stimulating its economic growth.

Iqbal and Islam (2014) examined the determinants of bilateral trade between Bangladesh and the European Union using panel data for the time period from 1980 to 2010. Using the gravity model and the Ordinary Least Square technique, empirical findings reveal that the GDP of Bangladesh is positively correlated with bilateral trade but the GDP of the European Union and bilateral real exchange rate are negatively correlated with trade. The study recommends that for the enhancement of trade between Bangladesh and the European Union, exportable goods from Bangladesh to the European Union should be well designed, diversified and price competitive with improved 
quality. Also, Bangladesh should improve compliance facilities, ensure political stability and improve utilities and port facilities. In addition, they recommend that the European Union (EU) should provide technical support, assist in the training of trade agents, provide long term Generalized System of Preferences (GSP) facilities and grant more quota free access to the EU market. Finally the study recommends that Bangladesh and the EU should keep the real exchange rate lower and Bangladesh should formulate relevant policies that advocate for the use of intensive labour in production.

Zeray and Gachen (2014) examined the determinants of bilateral trade between Ethiopia and its major trading partners for a ten year period from 2000 to 2009. With the use of the gravity model and the fixed effect estimation technique, the results revealed that bilateral trade flows was determined by the economic size of the importing and exporting countries, real bilateral exchange rate, foreign direct investment (FDI) of Ethiopia, weighted distance between Ethiopia and its major trading partners and the role of borders between Ethiopia and its major trading partners. The results of the study also indicate that a depreciation of the real exchange rate would affect the international competitiveness of Ethiopian exports. The study therefore recommends the depreciation of the country's real exchange rate for it will cause a gain in competitiveness. Finally, it is recommended that the government pays adequate attention to destination markets with cheaper transport costs.

Bonuedi (2013) examined the factors that determine Ghana's bilateral exports and total trade flows within the framework of an augmented gravity model. Utilizing a panel data covering 25 major trading partners of Ghana from 1995 to 2011, the study employs panel co-integration analysis, aside the conventional fixed effects and random effects estimators, to establish the existence of and to estimate the long run relationship among Ghana's bilateral total trade and exports and their respective determinants. The empirical results reveal that improvement in

Ghana's GDP and that of its partners, growth in foreign population, depreciation in real bilateral exchange rate, higher trade freedom of partners, and the inflow of foreign direct investment are robust positive and significant determinants of Ghana's bilateral exports and total trade. Geographical distance, Ghana's population and internal transport infrastructure are found to have significantly deleterious impact on Ghana's bilateral trade flows. It is also found that the level of Ghana's institutional quality and sharing common language with partners exert positive but statistically insignificant impact on the nation's bilateral trade flows. The study concludes that the current government's budgetary focus of massively expanding, upgrading and modernizing trade-related infrastructure in Ghana is a stride in the right direction and must be anchored with policies aimed at improving the overall efficiency and effectiveness of domestic institutions so as to create the needed incentives for economic agents, both at home and abroad, to engage in trade and invest in Ghana's exports sectors.

Garcia et al. (2013) examined the determinants of bilateral trade flows between seventy five MERCOSUR countries making use of the gravity model for the time period 1980 to 2008 . The model is augmented with variables that are relevant in determining the volume and direction of international trade using two alternative estimation methods; pooled ordinary least squares and panel fixed effects. The results reveal that the influence of the agreement on trade has been positive but moderate. As a whole, the results revealed that the signing of the MERCOSUR agreement has had positive effects. The study therefore recommends that the MERCOSUR agreement should be reinforced with the deepening of relationships between member countries and the entry of new members.

Khan et al. (2013) investigated Pakistan's bilateral trade flows with major trading partners for the time period from 1990 to 2010. Making use of the gravity model and Multiple Regression Analysis, the findings of the study reveal that GDP and GDP per capita positively affect trade volume while distance and dummy variable for cultural similarities showed a negative relationship towards trade volume. The study recommends that Pakistan should take initiatives to increase its trade with large economies as findings of the study showed a positive significant relationship between GDP and trade volume. Also, they recommend that political objectives should be settled according to economic objectives so that economic activities like trade may not suffer because of political disputes. Again, countries like Japan, Iran, India, Turkey and Malaysia should be considered for initiating trade agreements as findings of the study suggest larger percentages of unrealized trade potential with them. Lastly, trade with neighbouring countries should be increased as lower transportation costs may lead to an increase in the demand for exports and imports.

Ntembe (2012) examined the determinants of trade in the Central African Economic and Monetary Union (CEMAC) over a time period from 1998 to 2008. Using panel data for the six member States and fourteen trading partners, the study made use of the Fixed Effect Estimation Technique and a modified gravity model. The empirical results of the study reveal that membership in CEMAC did not increase bilateral trade flows among member States during the period under investigation. The results also highlight the importance of distance and being landlocked as obstacles to trade within the region and between CEMAC economies and overseas trading partners. Finally, the study recommends that measures to increase trade between CEMAC member countries as well as CEMAC member countries and its other trading partners should be encouraged.

Turkson (2012) sought to find out if EU trade preferences and Regional Trade Agreements within Sub- 
Saharan Africa (SSA) had increased bilateral trade flows. Estimating a gravity model augmented with measures of trade agreements, the study made use of bilateral trade flows and key covariates from the Centre D'Etudes Prospectives et D'Informations Internationales (CEPII) data base on seventy three countries (forty eight SSA countries and twenty five EU countries) over the time period 1960 to 2016 . After controlling for the endogeneity of the trade agreement dummy, accounting for multilateral price resistance and zero-valued trade flows, the findings indicate that the EU-African Caribbean and Pacific Group of States (ACP) PTA and RTAs within ECOWAS and SADC have a positive and significant impact on bilateral trade involving SSA countries. In some cases, the relative impact of sub-regional RTAs was found to be stronger than the EU-ACP non-reciprocal PTA. The study recommends that developing countries especially within Sub-Saharan Africa should focus on expanding and integrating regional markets in order to significantly improve trade performance.

Anaman and Atta-Quayson (2009) analysed the bilateral merchandise trade flows between

Ghana and the other fourteen members of the Economic Community of West African States (ECOWAS). The analysis made use of the modified gravity model based on most recent data from 1995 to 2006. The study established that per capita gross domestic product of ECOWAS countries and the population of these countries drive trade levels between Ghana and these countries in a positive manner as expected from the theoretical gravity model. The physical distance between Ghana and ECOWAS member countries had an expected negative impact on trade flows with longer distances reducing trade flows. Political instability in ECOWAS countries was also found to hinder bilateral trade between Ghana and these countries. It was also established that Ghana trades more intensively with French-speaking countries than other countries in the ECOWAS region. This result is partly due to Ghana sharing its border with three French-speaking countries. However the trade volumes between Ghana and other French speaking countries in the Region with which it does not share borders are also significant. The study recommends the widespread teaching and learning of the French language in Ghana.

Gani (2008) used a panel data from 1985 to 2002 examined factors influencing bilateral trade between Fiji and its Asian trade partners. With the use of a gravity model, he opined that Fiji's trade flows with these countries are determined by their GDPs, geographical distance, population and other influences such as exchange rate and infrastructure. Other variables except GDP were statistically significant. However, the study did not examine if regional trade agreement influenced Fiji's bilateral trade flows. The study recommends that policies that are geared towards boosting Fiji's bilateral trade flows should be designed and implemented.

Tri Do (2006) examined the bilateral trade between Vietnam and twenty three European countries based on a gravity model and panel data for years 1993 to 2004. Estimates indicate that economic size, market size and real exchange rate of Vietnam and twenty three European countries play major role in bilateral trade between Vietnam and these countries. Distance and history, however, do not seem to drive the bilateral trade. The results of gravity model are also applied to calculate the trade potential between Vietnam and twenty three European countries.

It shows that Vietnam's trade with twenty three European countries has considerable room for growth. The study recommends that the Vietnamese authorities should engage in policy actions that boost bilateral trade with its trading partners for this will go a long way in boosting economic growth.

Linders et al. (2005) examined the cultural and institutional determinants of bilateral trade flows by extending the basic gravity equation to include other variables such as cultural distance, institutional distance and institutional quality. Using the basic gravity model equation and the Ordinary Least Squares technique, they analysed a sample of bilateral trade flows between ninety-two countries in 1999. Their empirical findings reveal that institutional distance has a negative effect on bilateral trade presumably because the transaction costs of trade between partners with dissimilar institutional settings are high. Also, they found out that institutional quality of both the importer and exporter countries increases the amount of bilateral trade. The study recommends that institutional quality should be improved for this will go a long way in increasing bilateral trade flows.

De Groot et al. (2004) examined the effect of institutions on bilateral trade flows. Making use of the gravity model and the Ordinary Least Squares estimation technique, empirical findings on trade patterns in 1998 for a set of more than one hundred countries indicate that a similar institutional framework promotes bilateral trade by thirteen percent on average. In summary, the findings reveal that institutional quality and quality of governance have a significant, positive and substantial impact on bilateral flows.

\section{Methodological Issues}

The study covers a time period of forty six years from 1972 to 2018. (Twenty one years before the formation of the CEMAC trade bloc-1972 to 1993, and twenty five years after the formation of the CEMAC trade bloc- 1994 to 2018).

While data for total bilateral trade was obtained from the IMF's Direction of Trade Statistics, data for gross domestic product, population size and investment in fixed capital were obtained from the World Bank's World Development Indicators (2020). Data for distance and border dummy on their part were obtained from the Institute for Research on the International Economy (CEPII, 2020). The CEMAC dummy takes the value 0 for the twentyone year period before the formation of the CEMAC trade bloc (1972 to 1993) while the CEMAC dummy takes 
the value 1 for the twenty-five year period after the formation of CEMAC trade bloc (1994 to 2018).

The model for the determinants of bilateral trade within the CEMAC Bloc draws inspiration from the theoretical foundations of Tinbergen's gravity model (1962) and the empirical work of Zeray and Gachen (2014) who examined the determinants of bilateral trade between Ethiopia and its major trading partners.

The generalized gravity equation in its estimable panel form is given as;

$\mathrm{TBT}_{\mathrm{ijt}}=\beta_{0}+\beta_{1} \ln Y_{\mathrm{it}}+\beta_{2} \ln \mathrm{Y}_{\mathrm{jt}}+\beta_{3} \ln \mathrm{D}_{\mathrm{ijt}}+u_{\mathrm{it}}+\varepsilon_{\mathrm{it}}$

Where $\mathrm{i}=$ Home country or exporting country

$\mathrm{j}=$ Foreign country or importing country

$\mathrm{TBT}_{\mathrm{ijt}}=$ Total Bilateral trade flows between home (exporting) country and foreign (importing) country

$Y_{i}=$ GDP of home or exporting country

$Y_{j}=$ GDP of foreign or importing country

$\mathrm{D}_{\mathrm{ij}}=$ Distance between home (exporting) country and foreign (importing) country.

$\beta$ represents parameters to be estimated

$\varepsilon_{\text {it }}=$ Within-entity error

$u_{\text {it }}=$ Between-entity error

$\mathrm{it}=$ caters for the panel structure with $i=$ country entity and $t=$ time.

$\beta_{0}=$ constant term with $\beta_{1}>0, \beta_{2}>0$ and $\beta_{3}<0$

From equation (3.1) above, additional variables that affect bilateral trade can be added. Such variables include; population of home country, population of foreign country, physical capital in the home country, physical capital in the foreign country, the existence of a border between the home country and the foreign country and the possibility of the home country and the foreign country belonging to the same Regional Trade Agreement.

Given these additional variables and adopting and extending the empirical model by Zeray and Gachen (2014), the model for the determinants of bilateral trade in the CEMAC region within a panel data setting is given as;

$\operatorname{lnTBTijt}=\beta_{0}+\beta 1 \ln Y_{\mathrm{it}}+\beta 2 \ln Y j \mathrm{jt}+\beta 3 \ln \mathrm{lijt}+\beta 4 \mathrm{BORDijt}+\beta 5 \mathrm{POPit}+\beta 6 \mathrm{POPjt}+\beta_{7} \mathrm{PHYC}_{\mathrm{it}}+\beta_{8} \mathrm{PHYC}_{\mathrm{jt}}+$ $\beta$ CEMACijt $+u_{\text {it }}+\varepsilon_{\text {it }}$

where $\mathrm{i}=$ Home country or exporting country

$\mathrm{j}=$ Foreign or importing country

$\mathrm{TBT}_{\mathrm{ijt}}=$ Bilateral trade flows between home (exporting) country and foreign (importing)

country

$\mathrm{Y}_{\mathrm{i}}=$ GDP of home or exporting country

$Y_{j}=$ GDP of foreign or importing country

$\mathrm{D}_{\mathrm{ij}}=$ Distance between home (exporting) country and foreign (importing) country.

$\mathrm{BORD}_{\mathrm{ij}}=$ Dummy variable that takes the value 1 if home (exporting) country and foreign (importing) country share a common border and takes the value 0 if home (exporting) country and foreign (importing) country do not share a common border.

$\mathrm{PHYC}_{\mathrm{i}}=$ Home (exporting) country investment in fixed capital

$\mathrm{PHYC}_{\mathrm{j}}=$ Foreign (importing) country investment in fixed capital

CEMAC $_{\mathrm{ij}}=$ CEMAC dummy that takes the value 0 for time period where home (exporting) country and foreign (importing) country do not belong in the same CEMAC trade bloc (1972 to 1993) and takes the value 1 for the time period where home (exporting) country and foreign

(importing) country belong in the same CEMAC trade bloc (1994 to 2018).

$\varepsilon_{\text {it }}=$ Within-entity error

$u_{\text {it }}=$ Between-entity error

$\mathrm{it}=$ caters for the panel structure with $i=$ country entity and $t=$ time.

$\beta_{0}=$ constant term

with $\beta_{1}>0, \beta_{2}>0, \beta_{3}<0, \beta_{4}$ is a dummy which equals zero if home (exporting) and foreign (importing) country do not share a common border and equal one if home (exporting) and foreign (importing) country share a common border. $\beta_{5}>0, \beta_{6}>0, \beta_{7}>0, \beta_{8}>0$ and $\beta_{9}$ is the CEMAC dummy which takes the value zero for the time period before the formation of CEMAC (1972 to 1993) and takes the value one for the time period after the formation of CEMAC (1994 to 2018).

The main estimation technique used in this study is the Poisson Pseudo Maximum Likelihood (PPML) estimation technique. It is chosen over traditional gravity estimation techniques such as the Ordinary Least Squares (OLS) technique because it is consistent in the presence of fixed effects, it naturally includes observations for which the observed trade value is zero and it has the inbuilt capacity to take care of the problems of heteroskedasticity. The PPML estimation technique has been used extensively in the estimation of gravity equations by authors such as Bosquet and Boulhol (2015), Egger and Tarlea (2015), Dai et al. (2014), Lin (2013), Yotov (2012), de Souza (2012), Egger and Larch (2011), Head et al. (2010), Shepherd (2010) and Tenreyro (2007) amongst others.

To test for stationarity, this study makes use of the Hadri Lagrange Multiplier test better known as the Hadri (2000) LM test. The Hadri (2000) LM test uses panel data to test the null hypothesis that the data are stationary 
versus the alternative that at least one panel contains a unit root. The test is designed for cases with large samples and moderate observations. The motivation for the Hadri LM test is straight forward. Suppose we include a panel specific time trend and write our series $\mathrm{y}_{\mathrm{it}}$ as;

yit $=r_{i t}+\beta_{i t}+\varepsilon_{i t .}$ rit $=$

$\mathrm{r}_{\mathrm{i}, \mathrm{t}-1}+\mathrm{u}_{\mathrm{it}}$

where $\mathrm{r}_{\mathrm{it}}$ is a random walk and $\varepsilon_{\mathrm{it}}$ and $\mathrm{u}_{\mathrm{it}}$ are zero-mean independent and identically distributed normal errors. If the variance of $u_{i t}$ were zero, then $r_{i t}$ would collapse to a constant therefore implying that $y_{i t}$ would therefore be trend stationary.

Using this logic, the Hadri LM test tests the hypothesis $H_{0}: \lambda=\frac{\sigma_{u}^{2}}{\sigma_{\epsilon}^{2}}=0 \quad$ versus $H_{a}: \lambda>0$

Let $\widehat{\epsilon}_{i t}$ denote the residuals from a regression of $y_{i t}$ on a panel-specific intercept or a panel specific intercept and time trend if trend is specified. Then the Hadri LM statistic is given as

$$
\begin{aligned}
& \text { where } \widehat{\widehat{\mathrm{LM}}}=\frac{\frac{1}{N} \sum_{i} \frac{1}{T^{2}} \sum_{t} S_{i t}^{2}}{\widehat{\sigma}_{\epsilon}^{2}} \\
& \text { and } \quad \widehat{\sigma}_{\epsilon}^{2}=\frac{1}{N T^{\prime}} \sum_{i=1}^{N} \sum_{t=1}^{T} \widehat{\epsilon}_{i t}^{2} \quad \sum_{j=1}^{t} \widehat{\epsilon}_{i j}
\end{aligned}
$$

The Hadri LM test is chosen for this study over the other first and second generation unit root tests because it has the inbuilt technical statistical capacity to cater for heteroskedasticity, serial correlated errors and crossdependence.

\section{Presentation and Discussion of Findings}

4.1 Presentation and Discussion of the Hadri LM Stationarity Test

Table 4.1: Hadri LM Stationarity Test

$\mathrm{H}_{0}$ All panels are stationary

$\mathrm{H}_{1}$ : Some panels contain unit roots

\begin{tabular}{|l|l|l|}
\hline Variable & Statistic & P-Value \\
\hline Export & -1.4455 & 0.9258 \\
\hline Import & 0.9413 & 0.1733 \\
\hline Total trade & -0.0705 & 0.5281 \\
\hline GDP of home country & -3.0013 & 0.9987 \\
\hline GDP of foreign country & 0.7507 & 0.2264 \\
\hline Distance & -0.0950 & 0.5378 \\
\hline Home Country Population & -3.0013 & 0.9987 \\
\hline Foreign Country Population & 0.7507 & 0.2264 \\
\hline Physical capital of Home Country & -1.2958 & 0.9025 \\
\hline Physical capital of Foreign Country & -0.3948 & 0.6535 \\
\hline
\end{tabular}

\section{Source: Computed by Author using STATA (2020)}

As seen from Table 4.1 above, the Hadri LM Stationarity test reveals that all the variables are stationary. As already noted, the null hypothesis for the Hadri LM Stationarity test is stated as;

$\mathrm{H}_{0}$ : All panels are stationary

$\mathrm{H}_{1}$ : Some panels contain unit roots

Again, the decision rule for the Hadri LM Stationarity test is that we reject the null hypothesis if a variable has a probability value (p-value) of less than 0.05 . Thus, as seen from table 1 above, since all the variables have a probability value ( $\mathrm{p}$-value) of greater than 0.05 , we fail to reject the null hypothesis and therefore conclude that all the panels are stationary.

Precisely, the variables (export, import, total trade, GDP of home country, GDP of foreign country, distance, population of home country, population of foreign country, physical capital of home country and physical capital of foreign country) are therefore all stationary since they all have p-values of $0.9258,0.1733,0.5281,0.9987$, $0.2264,0.5378,0.9987,0.2264,0.9025$ and 0.6535 respectively which are all greater than 0.05 .

\subsection{Presentation and Discussion of the PPML Regression Results}

The PPML regression results for the determinants of bilateral trade within the CEMAC Bloc is presented in Table 4.2 below; 
Table 4.2 PPML Regression Results for the Determinants of Bilateral Trade within the CEMAC Bloc

\begin{tabular}{|c|c|c|}
\hline Intbt & $\begin{array}{c}\text { Coefficient } \\
\text { (Robust Standard Error) }\end{array}$ & P-Value \\
\hline gdph & 0.0229762 & 0.000 \\
\hline gdpf & $0.0021168)$ & \\
\hline ldist & $(0.00257289$ & 0.000 \\
\hline bord & -0.0119135 & 0.001 \\
\hline poph & $0.0978669)$ & 0.000 \\
\hline popf & $(0.0083503)$ & 0.000 \\
\hline phych & 0.0102314 & 0.000 \\
\hline phycf & 0.0102215 & \\
\hline cemacd & $(0.0053078)$ & 0.000 \\
\hline cons & 0.0151584 & \\
\hline R-Squared & $(0.0016828)$ & 0.000 \\
\hline
\end{tabular}

\section{Source: Computed by Author using STATA (2020)}

As seen from the PPML regression results in Table 4.2, results for home country GDP indicate that it has a positive impact on total bilateral trade. Precisely, a unit increase in home country GDP will increase total bilateral trade by $0.0229762 * 100 \%=2.29762 \%$. Results also indicate that the GDP of home country is statistically significant since its p-value is 0.000 which is less than 0.05 (p-value at $95 \%$ confidence interval).

Again, results for foreign country GDP indicate that it has a positive impact on total bilateral trade. Precisely, a unit change in foreign country GDP will increase total trade by $0.0257289 * 100 \%=2.57289 \%$. GDP for foreign country was found to be statistically significant since its p-value is 0.000 which is less than 0.05 (95\% confidence interval).

In addition, results for distance indicate that distance has a negative impact on total bilateral trade. Precisely, a $1 \%$ increase in distance will lead to a $0.0119135 \%$ decrease in total bilateral trade. Distance was found to be statistically significant since its p-value which is 0.001 is less than 0.05 (p-value at $95 \%$ confidence interval).

Furthermore, results for the border dummy reveal when a pair of CEMAC member States involved in bilateral trade share a common border, total bilateral trade increases by 0.0978669 . The border dummy was found to be statistically significant since its p-value which 0.000 is less than 0.05 (p-value at $95 \%$ confidence interval).

Again, results for home country population reveal that home country population has a positive impact on total bilateral trade. Precisely, if home country population increases by one unit, total bilateral trade will increase by $0.0102314 * 100 \%=1.02314 \%$. Population of home country was found to be statistically significant since its pvalue which is 0.000 is less than 0.05 (p-value at $95 \%$ confidence interval).

Likewise, results for foreign country population reveal that foreign country population has a positive impact on total bilateral trade. Precisely, if foreign country population increases by one unit, total bilateral trade will increase by $0.0102215 * 100 \%=1.02215 \%$. Population of foreign country was found to be statistically significant since its $\mathrm{p}$-value which is 0.000 is less than 0.05 (p-value at $95 \%$ confidence interval).

Moreover, results for home country physical capital reveal that home country physical capital has a positive impact on total bilateral trade. Precisely, if home country physical capital increases by one unit, total bilateral trade will increase by $0.0102314 * 100 \%=1.02314 \%$. Home country physical capital was found to be statistically significant since its $\mathrm{p}$-value is 0.000 which is less than 0.05 (p-value at $95 \%$ confidence interval).

Likewise, results for foreign country physical capital reveal that it has a positive impact on total bilateral trade. Precisely, if foreign country physical capital increases by one unit, total trade bilateral trade will increase by $0.0124459 * 100 \%=1.24459 \%$. Foreign country physical capital was found to be statistically significant since its $\mathrm{p}$-value is 0.000 which is less than 0.05 (p-value at $95 \%$ confidence interval).

Finally, the CEMAC dummy variable reveals that it has a negative impact on total bilateral trade. Precisely, after the creation of CEMAC as a regional trade bloc, total bilateral trade has decreased by 0.0655997 . However, the CEMAC dummy variable is statistically significant since its p-value is 0.000 which is less than 0.05 (p-value at $95 \%$ confidence interval). 
The PPML regression results presented in Table 4.3 above on the determinants of bilateral trade within the CEMAC bloc are discussed in the following paragraphs; Firstly, it was observed that home country GDP and foreign country GDP had positive and significant impact on intra-CEMAC country to country bilateral trade blows. These findings are in conformity with the findings of other authors such as Fatima et al. (2019), Irshad et al. (2019), Akpoilih and Farayibi (2015), Husain and Yasmin (2015), Panda et al. (2016), Iqbal and Islam (2014), Zeray and Gachen (2014), Bonuedi (2013), Khan et al. (2013), Anaman and Atta-Quayson (2009), Gani (2008) and Tri Do (2006) amongst other findings.

The findings are also in line with the predictions of Tinbergen's (1962) gravity model that predicts a direct relationship between bilateral flows and the GDP of the exporting country as well as the GDP of the importing country. It is worth noting that the GDP of a country represents the macro demand of the entire economy. So, higher GDP values means nationals of a country can buy more goods and services across national boundaries. It is therefore imperative that policy makers of the CEMAC bloc mobilize their productive and investment capacities in order to increase the GDP of their individual member States for this will go a long way in boosting intra-bloc country to country bilateral trade flows.

Next, it is observed that distance has a negative and significant impact on bilateral trade flows. The findings are in conformity with Tinbergen's (1962) gravity model that predicts that bilateral trade flows between two economies is negatively related to the distance between the two economies. These findings are also in conformity with the findings of other authors such as those of Fatima et al. (2019), Irshad et al. (2019), Akpoilih and Farayibi (2015), Panda et al. (2016), Anaman and Atta-Quayson (2009) and Gani (2008) amongst other findings.

The policy implication here is that policy makers of the CEMAC bloc should not consider distance between member States as an impediment to bilateral trade flows. They should rather invest in infrastructures such as road, railways, airways and telecommunication amongst others that will serve as a stimulant to efficient and rapid movement of goods, services, labour, capital, knowledge, skills and technology between member States. This will go a long way in minimising obstacles with respect to distance thereby boosting intra-CEMAC country to country bilateral trade.

In addition, the PPML regression findings reveal that the border dummy has a positive and significant impact on bilateral trade flows within the CEMAC bloc. The results are in conformity with the findings of Irshad et al. (2018) and Zeray and Gachen (2014). The policy implication here is that policy makers of the CEMAC trade bloc need to design and implement trade enhancing measures that improve trade especially between countries that do not share a common border. Such measures include the upgrade of infrastructure networks especially air infrastructure (the creation of AIR CEMAC) and the improvement of the investment climate for this will go a long way in boosting bilateral trade between CEMAC member States, especially those that do not share a common border.

Moreover, the PPML regression findings reveal that population of both exporting and importing countries has a positive and significant impact on intra-CEMAC country to country bilateral trade flows. The findings are in conformity with the findings of other authors such as Guan and Sheong (2020), Oparanya et al. (2019), Bonuedi (2013), Anaman and Atta-Quayson (2009) and Gani (2008).

Furthermore, the PPML regression findings reveal that physical capital of both exporting and importing countries has a positive and significant impact on intra-CEMAC country to country bilateral trade flows. The findings are in conformity with the findings of other authors such as Gani (2008). Excellent infrastructure facilitates the transport of goods, services, labour and technology across the borders of CEMAC member countries. It is therefore imperative that policy makers of the CEMAC bloc improve on their infrastructure (road, railway and air infrastructure) in a bid to boost bilateral trade between CEMAC member States.

Finally, the two PPML regression findings reveal that the CEMAC dummy variable has a negative and significant impact on bilateral trade flows between CEMAC member countries. The findings are in sharp contrast with economic a priori expectation since according to Lynch (2010), regional trade agreements (trade blocs) are expected to increase market access, increase competition, promote trade liberalization and encourage the free movement of goods, services, capital, labour, skills and technology.

The findings are in sharp contrast with the findings of other authors such as Irshad et al. (2018), Husain and Yasmin (2015), Garcia et al. (2013) and Turkson (2012) amongst others who found out that the creation of trade blocs rather act as platforms that boost bilateral trade. It is therefore vital that policy makers of the CEMAC bloc re-energize their efforts in designing and implementing policies such as improving transport infrastructure, investing in education and skilled human capital as well as implementing measures that improve the business climate most especially measures that ease trading across the borders of CEMAC member States. All these measures will go a long way in boosting trade within the CEMAC Bloc.

\section{Policy Recommendations}

Based on our objective which was aimed at examining the determinants of bilateral trade in the CEMAC trade bloc, the following policy recommendations could be made; 
Firstly, it is imperative that policy makers of CEMAC member States mobilize their productive and investment capacities in order to increase the GDP of their individual member States for this will give them more economic power to trade between each other. This will go a long way in boosting bilateral trade flows.

In addition, policy makers of the CEMAC bloc should not consider distance between CEMAC member countries as an impediment to bilateral trade flows. They should rather invest in infrastructures such as roads, railways, airports, sea ports and telecommunication networks amongst others. This will serve as a stimulant to the efficient and rapid movement of goods, services, labour and technology between CEMAC member States thereby minimising any negative hindrance with respect to distance and thereby boosting bilateral trade flows between CEMAC member States

Furthermore, policy makers of the CEMAC bloc should design and implement measures that completely eradicate physicals barriers and law enforcement control posts at the borders of their respective member States. This will go a long way in ensuring the smooth flow of goods, services, labour, technology and information between member States. Citizens of the CEMAC bloc should be allowed to circulate, trade, work and reside in any of the CEMAC member countries without any hindrance.

Finally, policymakers of the CEMAC bloc need to design and implement policies that improve the business (investment) climate of their economies. Such policies should be geared towards easing the procedures of starting a business, easing the procedures of getting construction permits, easing the procedures of registering property, easing the procedures of getting credit for investment, ensuring the protection of investors, easing the procedures of paying taxes, ensuring the enforcement of contracts, resolving issues of insolvency and above all facilitating trade across borders.

\section{References}

Akpoilih, R. and Farayibi, A., 2015. Determinants of Nigeria-China Bilateral Trade in Manufacturing Products. Munich Personal RePEc Archive, Paper No. 74183.

Anaman, K. A. and Atta-Quayson, A., 2009. Determinants of bilateral trade between Ghana and other members of the economic Community of West African states. IIUM Journal of Economics and Management 17 (2), 231-259. ISSN: 13947680.

Baier, L., Bergstrand, J. H., Feng, M. (2014). "Economic integration agreements and the margins of international trade". Journal of International Economics 93 (2), 339-350.

Baxter, M. and Kouparitsas, M. A., 2006. What Determines Bilateral Trade Flows? National Bureau of Economic Research Working Paper Series, 12188

Bernard, A. B.; J. Eaton; J. B. Jensen and S. Kortum (2003), Plants and Productivity in International Trade, American Economic Review 93(4): 1268-1290.

Bonuedi, I., 2013. Determinants of Ghana's bilateral trade flows: a gravity model approach Kwame Nkrumah University of science and technology, Kumasi.

Bosquet, C., Boulhol, H., 2015. What is really puzzling about the "distance puzzle"? Review of World Economy, volume 151, issue 1, pp. 1-21.

Dai, M., Yotov, Y.V. and Zylkin, T. (2014). "On the Trade-Diversion Effects of Free Trade Agreements". Economic Letters 122 (2), 321-325.

De Groot, H. L. F., Linders, G.J., Rietveld, P. and Subramanian, U., 2004. The Institutional Determinants of Bilateral Trade Patterns. Kyklos, Vol. 57, No.1: pp. 103-123.

De Sousa, J., 2012 . The currency union effect on trade is decreasing over time. Economics Letters, Volume 117 , pp. 917-920.

Egger, P. and Larch, M. (2011). “An assessment of the Europe agreements' effects on bilateral trade, GDP, and welfare". European Economic Review volume 55, pp. 263-279.

Egger, P. H. and Tarlea, F. (2015). "Multi-way clustering estimation of standard errors in gravity models". Economics Letters, Volume 134, pp. 144-147.

Fatima, K, Nisar, U and Yasmin, H (2019). "Factors Affecting the Bilateral Trade of Pakistan with Major Trading Partners". Journal of Economic Impact 1 (1), 19-28.

Gani, A., 2008. Factors Influencing Trade between Fiji and Its Asian Partners. Pacific Economic Bulletin, 23 (2), pp. 54-69.

García, E. C., Pabsdorf, M. N., and Herrera, E. G., 2013. The gravity model analysis: an application on MERCOSUR trade Flows. Journal of Economic Policy Reform, Vol. 16 (4).

Guan, Z and Ip Ping Sheong, J.K (2020), "Determinants of bilateral trade between China and Africa: a gravity model approach", Journal of Economic Studies, Vol. ahead-of-print No. ahead-of-print. https://doi.org/10.1108/JES-12-2018-0461.

Hadri, K. (2000). "Testing for stationarity in heterogeneous panel data". Econometrics Journal 3, 148-161.

Husain, S. and Yasmin, S., 2015. Does the Gravity Model Explain Bangladesh's Direction of Trade? A Panel Data Approach. IOSR Journal of Economics and Finance (IOSR-JEF) Volume 6, Issue 3. Ver. II), PP 01-14. 
Head, K., Mayer, T. and Ries, J., 2010. The Erosion of Colonial Trade Linkages After Independence. Journal of International Economics, volume 81, issue 1, pp. 1-14.

Iqbal, H and Islam, A. (2014). "Determinants of Bilateral Trade between Bangladesh and the European Union: Approach of gravity model under panel data. Issues in Business Management and Economics 2 (5), 87-93.

Irshad, M.S, Xin, Q, Hui, S and Arshad, H (2018). “An Empirical Analysis of Pakistan's Bilateral Trade and Trade Potential with China. A Gravity Model Approach”. Cogent Economics and Finance 6 (1), 1-18.

Kabir, M., Salim, R., and Al-Mawali, N., 2017. The gravity model and trade flows: Recent developments in econometric modelling and empirical evidence. Economic Analysis and Policy, Vol. 56, pp. 60-71.

Lin, F. (2013). “Are distance effect really a puzzle"? Economic Modelling, volume. 31, pp. 684689.

Linders et al. (2005). "Cultural and Institutional Determinants of Bilateral Trade Flows". Tinbergen Institute Discussion Paper 074/3.

Khan, S., Haq, I. and Khan, D. (2013). “An Empirical Analysis of Pakistan's Bilateral Trade: A Gravity Model Approach". The Romanian Economic Journal. Year XVI, no. 48.

Krugman, P. R., Obstfeld, M. and Melitz, M., 2012. International Economics, Theory and Policy, 9 edition. Boston: Addison-Wesley Pearson.

Krugman, P. (1979), A Model of Innovation, Technology Transfer, and the World Distribution of Income, Journal of Political Economy 87(2): 253-66.

Ntembe, A and Tawah, R. (2012). "The Determinants of Trade in the Central African Economic and Monetary Union”. Research in Business and Economics Journal 121177, 1-15.

Oparanya, A.W, Mdadila, K.P and Rutasitara, L.K (2019). "The Determinants of Bilateral Trade in the East African Community: Application of the Gravity Model". International Journal of Economics and Finance $11(4), 1-15$.

Osabuohien, E.S, Efobi, U.R, Odebiyi, J.T, Fayomi, O.O and Salami, A.O (2019). "Bilateral Trade Performance in West Africa: A Gravity Model Estimation": African Development Review 31 (1), 1-14.

Panda, R, Sethi, M and Kumaran, M. (2016). "A study of Bilateral Trade Flows of China and India". Indian Journal of Science and Technology 9 (15), 1-7.

Shepherd, B. (2010). "Geographic Diversification of Developing Country Exports". World Development 38 (9), 1217-1228.

Tenreyro, S. (2007). "On the trade impact of nominal exchange rate volatility". Journal of Development Economics, volume 82 , pp. $485-508$.

Tinbergen, J. (1962). Shaping the World Economy: Suggestions for and International Economic Policy. The Twentieth Century Fund: New York.

Tri Do, T. (2006). A Gravity Model for Trade between Vietnam and Twenty-Three European Countries. Department of Economics and Society, D Thesis 2006.

Turkson, F (2012). "Trade Agreements and Bilateral Trade in Sub-Saharan Africa: Estimating the Trade Effects of the EU-ACP PTA and RTAs. CREDIT Research Paper 12 (7), 1-34.

Umo-Udo, N.S and Orifa, J.A (2018). "Nigeria's Bilateral Trade Relations with China. An Assessment (19992016)". International Journal of Social Sciences and Management Research 4 (9), 1-14.

Yotov, Y. V., 2012. A simple solution to the distance puzzle in international trade. Economics Letters, Volume 117, pp 794-798.

Zeray, N and Gachen D (2014). "Determinants of Bilateral Trade between Ethiopia and Its Major Trading Partners: A Gravity Model Approach”. Journal of Economics and Sustainable Development 5 (15), 82-88. 